\title{
MtDNA diversity of the Indonesian giant barrel sponge Xestospongia testudinaria (Porifera: Haplosclerida) - implications from partial cytochrome oxidase 1 sequences
}

\author{
EDWIN SETIAWAN ${ }^{1,2,3}$, NICOLE J. DE VOOGD ${ }^{3}$, THOMAS SWIERTS ${ }^{3}$, JOHN N.A. HOOPER ${ }^{4,5}$, \\ GERT WÖRHEIDE ${ }^{1,6,7}$ AND DIRK ERPENBECK ${ }^{1,6}$ \\ ${ }^{1}$ Department of Earth and Environmental Sciences, Palaeontology \& Geobiology, Ludwig-Maximilians-Universität München, \\ Munich, Germany, ${ }^{2}$ Zoology lab, Biology Department, Mathematic and Natural Science Faculty, Sepuluh November Institute of \\ Technology, Surabaya, Indonesia, ${ }^{3}$ Naturalis Biodiversity Center, Leiden, the Netherlands, ${ }^{4}$ Biodiversity Program, Queensland \\ Museum, South Brisbane, Australia, ${ }^{5}$ Eskitis Institute for Drug Discovery, Griffith University, Nathan, Queensland 4111, Australia, \\ ${ }^{6}$ GeoBio-CenterLMU Ludwig-Maximilians-Universität München, Munich, Germany, ${ }^{7}$ SNSB - Bayerische Staatssammlung für \\ Paläontologie und Geologie, Munich, Germany
}

\begin{abstract}
The Indonesian archipelago is a 'hotspot' for invertebrate biodiversity ('Coral Triangle'). In this area of 'peak' biodiversity, the origins of this high species diversity have often been debated. Xestospongia testudinaria is one of the sponge species that dominates coral reef sponge communities in this region. The role of the so-called 'giant barrel sponge' for the reef ecosystem has been studied repeatedly, as have its various bioactive compounds. However, the genetic variation of this iconic sponge in the region remains unknown. We investigate over 200 barrel sponge samples from Indonesia, and neighbouring as well as more distant localities (Saudi Arabia, Tanzania, Thailand, Taiwan, Java, Sulawesi and the Great Barrier Reef, Australia) using the mitochondrial cytochrome oxidase subunit 1 . We compare our results with those from the studies on the congeneric barrel sponges Xestospongia muta from the Caribbean, and Xestospongia bergquistia from the Indo-Pacific, and observe a high degree of overlapping haplotypes between the three barrel sponge species, likely indicating the presence of ancestral polymorphisms. We discuss the implications of these findings to better interpret the phylogeography of barrel sponge taxa in the Indo-Pacific.
\end{abstract}

Keywords: Porifera, barrel sponges, Xestospongia, Indo-Pacific, taxonomy, mitochondrial DNA

Submitted 5 November 2014; accepted 19 June 2015; first published online 9 September 2015

\section{INTRDDUCTION}

The Indonesian archipelago forms a part of the 'Coral Triangle' (Veron, 1995), a region recognized for the high diversity of its marine species (Briggs, 1999; Hoeksema, 2007; Bellwood \& Meyer, 2009). However, the genetic diversity of the marine biota in this region remains incompletely studied and poorly understood (Veron, 1995; Hoeksema, 2007). Gaining this knowledge is pivotal to the assessment of genetic diversity within populations and species, and to understand past factors and future triggers of how organisms radiate and disperse in a given region. Such information is important for managing ecosystems and directing conservation efforts towards better resilience in times of global warming and sea-level changes (Sutherland et al., 2004; Jones et al., 2007; Lopez-Legentil \& Pawlik, 2009).

Sponges (Phylum Porifera) are an abundant and diverse group of marine organisms in the Indo-Pacific region, for

Corresponding author:

N.J. de Voogd and D. Erpenbeck

Emails: nicole.devoogd@naturalis.nl, erpenbeck@lmu.de which the genetic connectivity is also not fully understood (Wörheide et al., 2005; Bentlage \& Wörheide, 2007; Blanquer \& Uriz, 2007). Sponges play an important role in marine ecosystems due to their impact on substrate (e.g. as bioeroders, sediment aggregators, or for reef restoration), chemical cycling, symbiotic associations (see review in Bell, 2008) and might be a key component for the sustainability of reef ecosystems in oligotrophic seas (de Goeij et al., 2013). Sponge biodiversity studies have been shown to assist in monitoring the influence of environmental factors such as depth, light, tidal amplitude, water flow rate, temperature, velocity, salinity and suspended sediment load (Carballo et al., 1996; Bell, 2007; Cleary \& de Voogd, 2007; de Voogd \& Cleary, 2007; Becking et al., 2013). In addition, many sponge species contain various secondary metabolites, which have been a focus of drug discovery for decades (e.g. Newman \& Cragg, 2012).

An iconic sponge species in the Indonesian archipelago is the petrosiid demosponge Xestospongia testudinaria (Lamarck, 1815), also known as the 'Giant Barrel Sponge' (van Soest, 1989; van Soest et al., 2012). Xestospongia testudinaria is known to be widespread in the Indo-Pacific and is one of the more common species on Indonesian coral reefs (van 
Soest, 1989; de Voogd \& Cleary, 2008). Research on X. testudinaria has been focused mainly on new bioactive compounds (Calcul et al., 2003; Cao et al., 2005), ecology (Powell, 2013), aspects of reproduction (Fromont, 1988; Fromont \& Bergquist, 1994) and taxonomy (Fromont, 1991). More recently, research was conducted on the genetic connectivity of $X$. testudinaria, but so far only in a narrow geographic scale in northern (Swierts et al., 2013) and south-east Sulawesi (Bell et al., 2014a). Swierts et al. (2013) found that in an area of less than $200 \mathrm{~km}^{2}, X$. testudinaria comprises four distinct morphotypes, which are not obviously affected by environmental factors, and could be differentiated using mitochondrial and nuclear markers. One of the most intriguing findings of that work was the overlap of mitochondrial haplotypes between the Indo-Pacific X. testudinaria with the Caribbean barrel sponge Xestospongia muta (Schmidt, 1870) (see also Montalvo \& Hill, 2011). These intriguing findings highlight the need for a better understanding of barrel sponge species and population structures on a wider, preferably global scale. This study should include a critical re-evaluation of how sponge species have been delineated in the past, and can act as models for the future (see e.g. Solé-Cava \& Wörheide, 2007), using barrel sponges as an example.

Throughout the entire history of sponge systematics (see Boury-Esnault, 2006) morphological apomorphies and specific character combinations were the major discriminatory factors in taxonomy (cf. Diagnosable Species Concept, see de Queiroz, 2007). Even now, the most recent supra-specific classification of sponges, Systema Porifera (Hooper \& van Soest, 2002), is predominantly based on morphological criteria. This concept, however, apparently fails to distinguish between all barrel sponge species. On the one hand few morphological features differentiate $X$. testudinaria from a second Indo-Pacific barrel sponge species, $X$. bergquistia Fromont (Fromont, 1991), as recently supported by molecular (microsatellite) data (Bell et al., 2014a, b). However, so far there have been no unequivocal morphological apomorphies established to differentiate these two Pacific species from the Caribbean $X$. muta barrel sponge. Likewise, biochemical compounds, occasionally used as a source for apomorphies in demosponges (Erpenbeck \& van Soest, 2007), are inconclusive for barrel sponges. One $X$. muta specimen shared a similar, but not species-specific sterol composition to $X$. bergquistia specimens, and this was different from those found in specimens of X. testudinaria (Fromont et al., 1994).

Ecological parameters can provide apomorphies to differentiate sponge species (see e.g. Wapstra \& van Soest, 1987), where taxa are distinguishable by their respective ecological niches (cf. Ecological Species Concept, see de Queiroz, 2007). For example, among the oviparous and gonochoric barrel sponges, different spawning periods act as a potential reproductive barrier between the two Indo-Pacific taxa X. testudinaria and X. bergquistia (Fromont, 1988; Fromont \& Bergquist, 1994). Likewise, the geographic distance and continental barrier that separates the Caribbean X. muta from the Indo-Pacific barrel sponges acts as a potential reproductive barrier and is regarded as an important distinguishing feature (Montalvo \& Hill, 2011).

The advent of molecular systematics in sponges (Kelly-Borges et al., 1991) facilitated the delimitation of taxa based on the coalescence or common ancestry of lineages (Monophyletic and Genealogical Species Concepts, de Queiroz, 2007) (see examples in Cárdenas et al., 2012).
Many genetic analyses of barrel sponge species use the mitochondrial cytochrome oxidase subunit 1 ( $\operatorname{cox} 1)$, particularly its $3^{\prime}$ partition, which is shown to better resolve species-level differences than the standard barcoding fragment (Erpenbeck et al., 2006b). The $3^{\prime}$ partition enabled the recognition of four $X$. muta haplotypes in the Caribbean (Lopez-Legentil \& Pawlik, 2009), and six among Indo-Pacific barrel sponges (Swierts et al., 2013). Swierts et al. (2013) however, also corroborated earlier studies that failed to distinguish the geographically separated $X$. muta and $X$. testudinaria based on cox 1 sequences alone (Montalvo \& Hill, 2011). So far, barrel sponge cox1 contradicts earlier studies on the use of this marker for unravelling demosponge species level phylogenies (Erpenbeck et al., 2006a) (see also Lopez-Legentil \& Pawlik, 2009; Xavier et al., 2010; Reveillaud et al., 2011).

These findings prompted the present study, which aims to analyse the haplotype diversity of barrel sponges at the largest geographic scale attempted so far, stretching from the western Indian Ocean to the west Pacific, and including the type material of all three barrel sponge species. We explore the suitability of one of the most frequently used mitochondrial markers, cox1, to distinguish the three barrel sponge species. Furthermore, this study aims to further our understanding of the genetic population structure of the barrel sponge species at a much wider geographic scope than previous studies that were limited to populations surrounding Sulawesi (Swierts et al., 2013; Bell et al., 2014a).

\section{MATERIALS AND METHODS}

Fragments of 187 specimens of Xestospongia testudinaria were freshly collected from three regions: Java (West, Central, and East), Bali and Sulawesi (Lembeh, Spermonde, Wakatobi). Immediately after collection, samples were cut, rinsed and soaked in $99 \%$ ethanol before being kept in fresh $99 \%$ ethanol. An additional 24 samples were studied from Saudi Arabia, Tanzania, Taiwan and Thailand, provided by the Naturalis Biodiversity Center, Leiden, the Netherlands, and samples from the Great Barrier Reef (GBR) and Solomon Islands provided by the Queensland Museum (QM) Brisbane, Australia. Furthermore, the Queensland Museum also provided five individuals of Xestospongia bergquistia, including the holotype specimen (see Supplementary Material). In addition, we also obtained the neotype (BMNH 1881.10.21.266) and another, associated specimen of Ridley's (1881) material (BMNH 1881.10.21.267) of X. testudinaria from the British Museum of Natural History, London (Hooper \& Wiedenmayer, 1994). For Xestospongia muta, two syntypes were investigated (MCZ PORa-6449, MCZ PORa-6450, of which we designate the former as lectotype) and additional sequences were taken from GenBank (http://www.ncbi.nlm.nih.gov).

Samples were extracted based on previously published methods established for sponge barcoding (Vargas et al., 2012). The I3-M11 partition of cox1 was amplified with the Polymerase Chain Reaction (PCR) using primers CJ-J2165 and C1-Npor 2760 (Erpenbeck et al., 2002). The $25 \mu \mathrm{L}$ PCR mix consisted of $5 \mu \mathrm{L} 5 \times$ green GoTaq ${ }^{\circledR}$ PCR Buffer (Promega Corp, Madison, WI), $4 \mu \mathrm{L} 25 \mathrm{mM} \quad \mathrm{MgCl}_{2}$ (Promega Corp, Madison, WI), $2 \mu \mathrm{L} 10 \mathrm{mM}$ dNTPs, $1 \mu \mathrm{L}$ each primer $(5 \mu \mathrm{M}), 9.8 \mu \mathrm{L} \mathrm{H} \mathrm{H}_{2} \mathrm{O}, 0.2 \mu \mathrm{L}$ GoTaq $^{\circledR}$ DNA 
polymerase $\left(5 \mu \mu \mathrm{L}^{-1}\right)$ and $2 \mu \mathrm{L}$ DNA template. The PCR regime comprised an initial denaturation at $94^{\circ} \mathrm{C}$ for $3 \mathrm{~min}$, 35 cycles of $30 \mathrm{~s}$ denaturation at $94^{\circ} \mathrm{C}, 20 \mathrm{~s}$ annealing at $42^{\circ} \mathrm{C}$ and $60 \mathrm{~s}$ elongation at $72^{\circ} \mathrm{C}$ each, followed by a final elongation at $72^{\circ} \mathrm{C}$ for $5 \mathrm{~min}$. Re-amplifications with an internal primer set of the partition $\mathrm{I}_{3}-\mathrm{M}_{11}$ (CO1porF1 and CO1porR1, Erpenbeck et al., 2003) and combinations (CJ-J2165 - CO1porR1 and CO1porF1 - C1-Npor 2760) were required for obtaining PCR products from the type specimen of $X$. bergquistia. For the 133 year old specimen of $X$. testudinaria (BMNH 1881.10.21.267), the primer set CJ-J2165 and COX1-R1 (5'-TGTTGRGGGAAAAARG TTAAATT- $3^{\prime}$ ) (Rot et al., 2006) was amplified under the use of additional $2 \mu \mathrm{L}$ Bovine Serum Albumin (BSA, $10 \mathrm{mg}$ $\mathrm{mL}^{-1}$ ) and the PCR regime of $45 \mathrm{~s}$ annealing at $42^{\circ} \mathrm{C}, 45 \mathrm{~s}$ elongation at $72^{\circ} \mathrm{C}$ and a final elongation at $72^{\circ} \mathrm{C}$ for $7.5 \mathrm{~min}$. All of the PCR products were cleaned by ammonium acetate precipitation. Sequencing of forward and reverse strand was performed with the ABI BigDye v3.1 chemistry (Applied Biosystems, CA, USA) and the amplification primers following the manufacturer's protocol on an $\mathrm{ABI}$ 3730 Automated Sequencer in the Genomic Sequencing Unit of the LMU Munich. Sequences were assembled, trimmed and analysed by Geneious version 6.1.7 (http://www.geneious. com). Sequences were checked with BLAST against GenBank (http://www.ncbi.nlm.nih.gov) for contaminations. In total 211 sequences were aligned with MUSCLE version 3.5 (Edgar, 2004) as implemented in Geneious under default settings. Sequences of $X$. testudinaria, which are identical to the haplotype of sequences in the study of Swierts et al. (2013), are numbered according to that study (haplotypes C1-C6, GenBank accession numbers KC424439-KC424444). Conversely, new haplotypes (one haplotype $\mathrm{C}_{7}$, two type specimens (X. testudinaria and X. bergquistia) and one X. bergquistia haplotype) were submitted and deposited to NCBI GenBank under accession numbers KMo14752-KMo14755.

TCS v 1.21 (Clement et al., 2000) was used to create a statistical parsimony haplotype network among the analysed barrel sponges (X. testudinaria, X. bergquistia and X. muta) to map barrel sponge haplotype distributions according to their localities. DnaSP v. 5.10.01 (Librado \& Rozas, 2009) was recruited to obtain genetic diversity indices $(\pi)$ and to test neutral evolution of $\mathrm{I}_{3}-\mathrm{M}_{11}$ alleles from $X$. testudinaria by calculating Tajima's D (Tajima, 1989). For the analysis of the genetic structure of $X$. testudinaria, regional samples were pooled as follows: Saudi Arabia $(\mathrm{N}=3)$, Tanzania $(\mathrm{N}=13)$, Taiwan $(\mathrm{N}=7)$, Thailand $(\mathrm{N}=12)$, west Java $(\mathrm{N}=14)$, central Java $(\mathrm{N}=9)$, east Java \& Bali \& Sumba $(\mathrm{N}=10)$, north Sulawesi $(\mathrm{N}=126)$, south \& southeast Sulawesi $(\mathrm{N}=10)$, and the GBR and Solomon Islands $(\mathrm{N}=$ 7). A hierarchical analysis of molecular variance (AMOVA) was performed and pairwise $F_{\mathrm{ST}}$ values calculated in Arlequin v 3.5.1.2 (Excoffier et al., 2005) with a permutation test of 10,000 replicates. The significance of $F_{\mathrm{ST}}$ values was amended after a Bonferroni correction (Rice, 1989). Phylogenetic reconstructions among barrel sponges were performed under Maximum-likelihood (ML) and Bayesian inferences criteria. A Maximum-likelihood phylogram was inferred by RAxML v. 7.0.4 in raxmlGUI v. 1.3 (Silvestro \& Michalak, 2012) using 1000 rapid bootstrap replications (Stamatakis et al., 2008) and the GTR $+\mathrm{I}+\Gamma$ model as suggested by jModeltest v. 2.1.3 (Darriba et al., 2012) under the Akaike Information Criterion (Akaike, 1974). Likewise, a Bayesian phylogram was inferred using MrBayes v. 3.2.1 (Ronquist et al., 2012) under the same model of evolution. Each analysis consisted of two independent runs of four Metropolis-coupled Markov-chains under default temperature with trees sampled at every 10ooth generation. Analyses were terminated automatically when the chains converged significantly as indicated by an average standard deviation of split frequencies $<0.01$.

Spicule re-measurements were made for the three type specimens of barrel sponges $X$. testudinaria (BMNH 1881.10.21.266), $X$. bergquistia (QM G25018) and X. muta (MCZ PORa-6449). Spicule preparations were made by dissolving a small piece of the specimen in commercial bleach, after which the residue was rinsed four times with water, and once with $96 \%$ ethanol. The spicules were air-dried on microscopic slides and prepared for study with a light microscope by mounting in Ultrabed. Spicule dimensions are given as the mean length times mean width of 25 spicule measurements.

\section{RESULTS}

We obtained partial cox1 sequences (I3-M11 partition) of 211 specimens of Xestospongia testudinaria and six of X. bergquistia resulting in an alignment of 544 base pairs with six different haplotypes (Table 1). No amplification product for the neotype of $X$. testudinaria BMNH 1881.10.21.266, and the type material of X. muta MCZ PORa-6449 and MCZ PORa-6450 could be obtained. Five haplotypes were identical to haplotypes reported from Swierts et al. (2013) (C1, C2, C4-C6), whose labelling system is followed here; one novel haplotype was discovered and was subsequently named $\mathrm{C}_{7}$.

All six haplotypes were present in X. testudinaria (Figure 1). Two haplotypes are shared between $X$. testudinaria and X. bergquistia (Haplotype $\mathrm{C}_{2}$ and $\mathrm{C}_{5}$ ). The holotype of $X$. bergquistia (QM G25018) possessed the $\mathrm{C}_{5}$ haplotype and $X$. testudinaria $\mathrm{BMNH} 1881.10 .21 .267$ possessed the $\mathrm{C}_{2}$ haplotype. These sequences differed by an uncorrected $p$-distance of 0.0092 . The inclusion of previously published Xestospongia cox1 sequences from GenBank revealed that two haplotypes $\left(\mathrm{C}_{2}\right.$ and $\mathrm{C}_{5}$ ) are shared between the Indo-Pacific and Caribbean barrel sponge species. The 116 specimens of the Caribbean barrel sponge (Xestospongia muta) had a total of four haplotypes. Two of these haplotypes $\left(\mathrm{H}_{2}\right.$ and $\mathrm{H}_{4}$, as defined by Lopez-Legentil \& Pawlik, 2009), are not shared with the Indo-Pacific specimens (see Tables $1 \& 2$ ).

A close genealogical relationship among haplotypes was observed (Figure 2). All haplotypes were connectable with a maximum of one inferred mutational step. Haplotype $\mathrm{C}_{1}$ is the most abundant haplotype among the Indo-Pacific samples, comparable with $\mathrm{H}_{1}$ in the Caribbean (cf. Lopez-Legentil \& Pawlik, 2009) - with one mutational step separating those two major haplotypes. Haplotypes $\mathrm{C}_{5}$ and $\mathrm{C} 1$ were the dominant haplotypes in the Indonesian archipelago, from which the majority of specimens of $X$. testudinaria used in this study were collected. Haplotype $\mathrm{C}_{7}$ was exclusively found in the 13 samples from Tanzania, which in total displayed four different haplotypes. Among the three samples from the Red Sea, Saudi Arabia, only $\mathrm{C}_{5}$ was found (Figures $1 \&$ 2). In the reconstructed phylogram the barrel sponges are recovered as monophyletic with high support (Figure 3 ). However, as expected from the overlapping haplotypes, the cox1 fragment fails to support the monophyly of any of the three barrel sponge species. 
Table 1. Haplotypes recovered from the Xestospongia barrel sponge alignment. Positions refer to the full cox1 sequence from Xestospongia muta EU716653 (Kayal \& Lavrov, 2008); $\mathrm{C}_{1}-\mathrm{C}_{7}$, haplotype annotation follows Swierts et al. (2013); $\mathrm{H}_{1}-\mathrm{H}_{4}$, follows the labelling of Lopez-Legentil \& Pawlik (2009).

\begin{tabular}{|c|c|c|c|c|c|c|c|c|}
\hline Position (bp) & $\begin{array}{l}6 \\
6\end{array}$ & $\begin{array}{l}7 \\
7\end{array}$ & $\begin{array}{l}8 \\
3\end{array}$ & $\begin{array}{l}8 \\
8\end{array}$ & $\begin{array}{l}\mathbf{1} \\
\mathbf{0} \\
\mathbf{2}\end{array}$ & $\begin{array}{l}\mathbf{1} \\
\mathbf{8} \\
\mathbf{2}\end{array}$ & $\begin{array}{l}\mathbf{2} \\
\mathbf{1} \\
\mathbf{8}\end{array}$ & $\begin{array}{l}\text { Species; Reference (associated haplotype } \\
\text { number as used in reference) and example } \\
\text { GenBank accession number }\end{array}$ \\
\hline C1 (cf. Swierts et al. 2013) & A & $\mathrm{T}$ & $\mathrm{C}$ & A & G & G & $\mathrm{T}$ & $\begin{array}{l}\text { X. testudinaria; (Montalvo \& Hill, 2011) e.g. HQ452959 } \\
\text { X. testudinaria; (Swierts et al. 2013) e.g. KC424439 } \\
\text { X. testudinaria; (this study) }\end{array}$ \\
\hline C2 (cf. Swierts et al. 2013) & A & $\mathrm{T}$ & $\mathrm{C}$ & A & G & G & $\mathrm{C}$ & $\begin{array}{l}\text { X. muta; (Lopez-Legentil \& Pawlik, 2009) (as H1 e.g. EU716652) } \\
\text { X. testudinaria; (Swierts et al. 2013) e.g. KC } 424440 \\
\text { X. bergquistia; KMo14752 and X. testudinaria; (this study) }\end{array}$ \\
\hline $\mathrm{C}_{4}$ (cf. Swierts et al. 2013) & $\mathrm{A}$ & $\mathrm{T}$ & $\mathrm{C}$ & $\mathrm{C}$ & G & G & $\mathrm{C}$ & $\begin{array}{l}\text { X. testudinaria; (Swierts et al. 2013) e.g. KC424442 } \\
\text { X. testudinaria; (this study) }\end{array}$ \\
\hline $\mathrm{C}_{5}$ (cf. Swierts et al. 2013) & A & A & $\mathrm{C}$ & $\mathrm{C}$ & G & G & $\mathrm{C}$ & $\begin{array}{l}\text { X. muta; (Lopez-Legentil \& Pawlik, 2009) (as } \mathrm{H}_{3} \text { e.g. EU716654) } \\
\text { X. testudinaria; (Swierts et al. 2013) e.g. KC } 424443 \\
\text { X. bergquistia; KMo14753 and X. testudinaria (this study) }\end{array}$ \\
\hline C6 (cf. Swierts et al. 2013) & G & $\mathrm{A}$ & $\mathrm{C}$ & G & G & G & $\mathrm{C}$ & $\begin{array}{l}\text { X. testudinaria; (Montalvo \& Hill, 2011), e.g. HQ452960 } \\
\text { X. testudinaria; (Swierts et al. 2013) e.g. KC424444 } \\
\text { X. testudinaria; (this study) }\end{array}$ \\
\hline $\mathrm{C}_{7}$ (this study) & A & A & $\mathrm{C}$ & $\mathrm{C}$ & G & $\mathrm{T}$ & $\mathrm{C}$ & X. testudinaria; KMo14755 (this study) \\
\hline H2 (cf. Lopez-Legentil \& Pawlik, 2009) & A & $\mathrm{T}$ & $\mathrm{T}$ & A & G & G & $\mathrm{C}$ & $\begin{array}{l}\text { X. muta; (Lopez-Legentil \& Pawlik, 2009) e.g. EU716653 } \\
\text { X. muta; (Kayal \& Lavrov, 2008) e.g. EU23749o }\end{array}$ \\
\hline $\mathrm{H}_{4}$ (cf. Lopez-Legentil \& Pawlik, 2009) & G & A & $\mathrm{C}$ & G & A & G & $\mathrm{C}$ & X. muta; (Lopez-Legentil \& Pawlik, 2009) e.g. EU716653 \\
\hline
\end{tabular}

The nucleotide diversity $(\pi)$ value of $X$. testudinaria was 0.0029 and Tajima's D $1.65911(P>0.1)$, which indicated neutral evolution of the $\mathrm{I}_{3}-\mathrm{M}_{11}$ fragment. Furthermore, samples from four regions (Thailand, West Java, North Sulawesi and GBR + Solomon Islands) displayed significantly different population structures from the other localities (see
Table 3). Moreover, the hierarchical AMOVA analysis revealed that $32.49 \%$ of the genetic variation was found among populations and $67.51 \%$ within populations (see Table 4). Likewise, the overall $F_{\mathrm{ST}}$ value $(0.32491, P<0.05)$ indicated the presence of genetic structuring of $X$. testudinaria in the Indo-Pacific area.

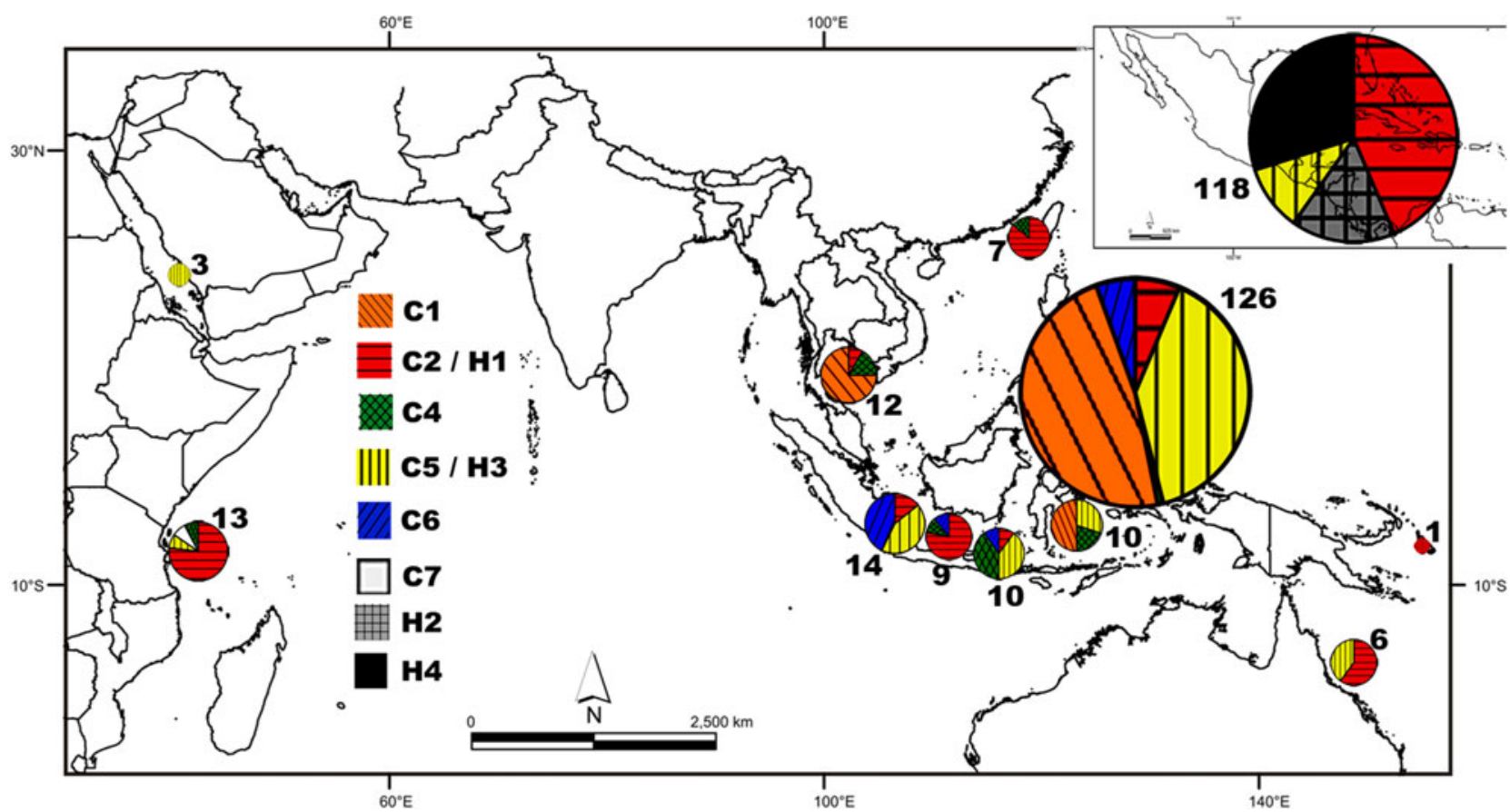

Fig. 1. Haplotype distribution of Xestospongia barrel sponge sequences used in this study. The size in the pie charts is proportional to the sample size. Different haplotypes are colour- and pattern-coded (see Tables 1 \& 2 for further details). Inset: Samples from the Caribbean (published by Kayal \& Lavrov, 2008; Lopez-Legentil \& Pawlik, 2009). C1-C7 haplotype annotations follow Swierts et al. (2013), whereas H1-H4 follow Lopez-Legentil \& Pawlik (2009). 
Table 2. Haplotype distribution of Xestospongia testudinaria and other barrel sponges according to their geographic localities. Haplotype annotation follows Swierts et al. (2013) and Lopez-Legentil \& Pawlik (2009)

\begin{tabular}{|c|c|c|c|c|c|c|c|c|c|c|c|c|}
\hline \multirow[t]{2}{*}{ Haplotype } & \multirow{2}{*}{$\begin{array}{l}\text { Saudi } \\
\text { Arabia }\end{array}$} & \multirow[t]{2}{*}{ Tanzania } & \multirow[t]{2}{*}{ Taiwan } & \multirow{2}{*}{$\begin{array}{l}\text { Thailand } \\
\& \\
\text { Singapore }\end{array}$} & \multicolumn{5}{|c|}{ Indonesian Archipelago } & \multirow{2}{*}{$\begin{array}{l}\text { Great } \\
\text { Barrier } \\
\text { Reef \& } \\
\text { Solomons }\end{array}$} & \multirow{2}{*}{$\begin{array}{l}\text { Florida, } \\
\text { Bahamas, }^{\text {Belize }}{ }^{d}\end{array}$} & \multirow[t]{2}{*}{ Tota } \\
\hline & & & & & $\begin{array}{l}\text { West } \\
\text { Java }\end{array}$ & $\begin{array}{l}\text { Central } \\
\text { Java }\end{array}$ & $\begin{array}{l}\text { East } \\
\text { Java, } \\
\text { Bali, } \\
\text { Sumba }\end{array}$ & $\begin{array}{l}\text { North } \\
\text { Sulawesi }\end{array}$ & $\begin{array}{l}\text { South and } \\
\text { Southeast } \\
\text { Sulawesi }\end{array}$ & & & \\
\hline $\mathrm{C}_{1}$ & 0 & o & o & 9 & o & 0 & o & 60 & 5 & o & o & 74 \\
\hline $\mathrm{C}_{2}$ & 0 & 10 & 6 & 1 & 2 & 7 & 1 & 8 & o & $8^{\mathrm{b}}$ & 51 & 94 \\
\hline $\mathrm{C}_{4}$ & o & 1 & 1 & 2 & o & 1 & 4 & 1 & 2 & 0 & o & 12 \\
\hline $\mathrm{C}_{5}$ & 3 & 1 & o & $1^{a}$ & 6 & 0 & 4 & 50 & 3 & $4^{c}$ & 12 & 84 \\
\hline C6 & 0 & o & o & o & 6 & 1 & 1 & 7 & o & 0 & o & 15 \\
\hline $\mathrm{C}_{7}$ & 0 & 1 & o & o & o & 0 & o & o & o & 0 & 0 & 1 \\
\hline $\mathrm{H}_{2}$ & 0 & o & o & o & o & 0 & o & o & o & 0 & $19^{\mathrm{e}}$ & 19 \\
\hline $\mathrm{H}_{4}$ & 0 & o & o & o & o & 0 & o & o & o & 0 & 35 & 35 \\
\hline Total & 3 & 13 & 7 & 13 & 14 & 9 & 10 & 126 & 10 & 12 & 118 & 334 \\
\hline
\end{tabular}

ane Xestospongia bergquistia specimen from Singapore.

${ }^{\mathbf{b}}$ Including one specimen of X. bergquistia from the Great Barrier Reef and one Ridley (1881) specimen of X. testudinaria (BMNH 1881.10.21.267).

${ }^{\mathrm{c}}$ Four specimens (including one holotype) of X. bergquistia.

dTaken from Lopez-Legentil \& Pawlik (2009).

e Including full mt genome sequence of X. muta (see Kayal \& Lavrov, 2008).

\section{DISCUSSION}

\section{Cytochrome oxidase 1 and barrel sponge species differentiation}

Currently the three barrel sponge species Xestospongia testudinaria, X. muta and X. bergquistia cannot be differentiated using the I3-M11 partition of cox1, which was suggested as a candidate marker for species level phylogenies other than the standard barcoding marker (Erpenbeck et al., 2006b), or by using any morphological or ecological parameter alone. The three barrel sponge species therefore can be regarded as 'Gray zone species' (de Queiroz, 2007) given our current understanding of them. The concept of Gray zone species

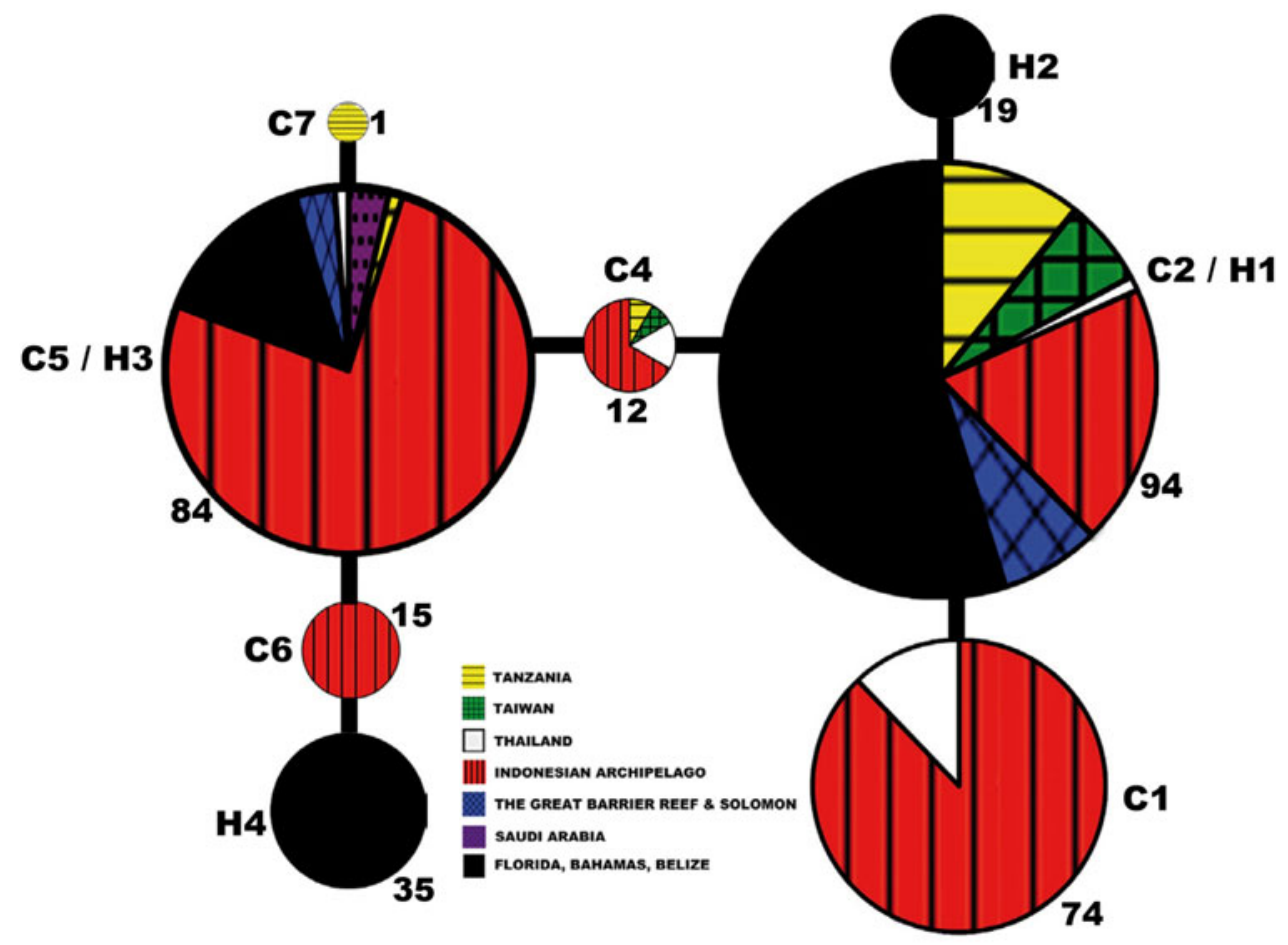

Fig. 2. Haplotype network of the Xestospongia barrel sponge specimens with respect to their sampling location (see Tables 1 \& 2 for details). Xestospongia muta sequences: (Kayal \& Lavrov, 2008; Lopez-Legentil \& Pawlik, 2009). $\mathrm{C}_{1}-\mathrm{C}_{7}$ haplotype annotations follow Swierts et al. (2013), whereas $\mathrm{H}_{1}-\mathrm{H}_{4}$ follow Lopez-Legentil \& Pawlik (2009). Numbers indicate the number of sequences analysed. 


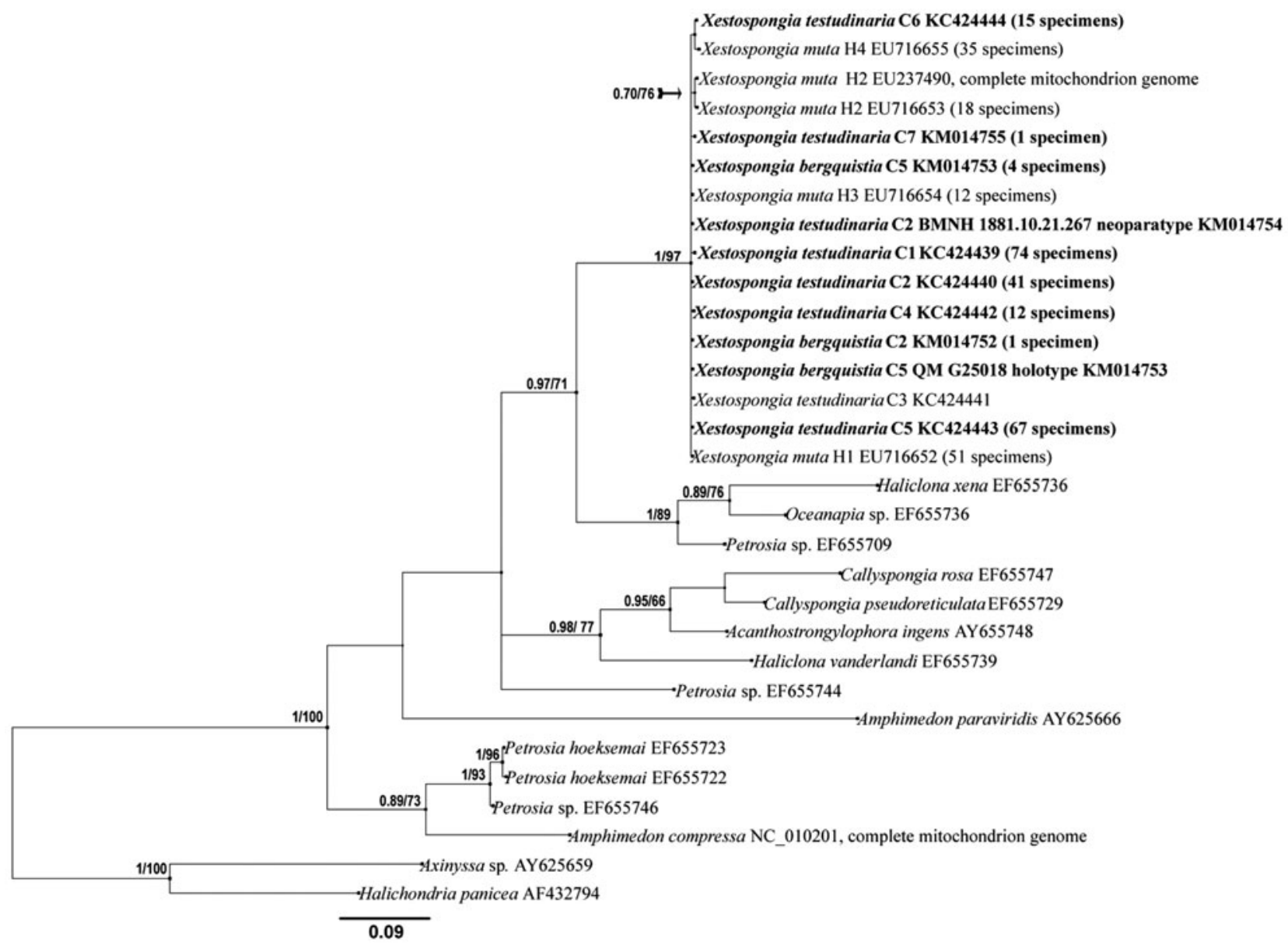

Fig. 3. Bayesian inference phylogram of Xestospongia barrel sponge haplotypes included in the analysis and other marine haplosclerid taxa. New sequences are given in bold and followed by the number of sequences obtained in this study, including GenBank accession numbers. The haplotype annotations follow Swierts et al. (2013) and Lopez-Legentil \& Pawlik (2009). Numbers on the branches represent posterior probabilities (PP)/bootstrap proportions (BP) of maximum likelihood analyses. Scale bar indicates the number of substitutions/site.

arises when there are differences in the views of species concepts, which then lead to conflicts in species delimitation (de Queiroz, 2007). Nevertheless, despite the overlapping haplotypes observed here, the three Xestospongia taxa cannot constitute a single species as evident from their morphological and biochemical differences. No unique character distinguishing the three species has yet been found. The measured spicules of all three type specimens revealed overlapping spicule dimensions (see Table 5). However, with respect to the two Indo-Pacific species, the magnitude of spongin reinforcement in the skeletons (Fromont, 1991) and microsatellite data (Bell et al., 2014b) supported species separation.

In terms of ecological parameters, the three species of barrel sponges constitute different species based on reproductive behaviour (Fromont, 1988, Ritson-Williams et al., 2005), and by their wide geographic separation (Montalvo \& Hill, 2011). Contact zones between the Indo-Pacific and the Caribbean barrel sponges do not exist. While gene flow between barrel sponge populations in the Caribbean and the Indo-Pacific via ballast water from ships or vessels travelling through the Panama Canal is possible (Ruiz et al., 2007), it is unlikely to cause or explain the haplotype patterns observed in this study. No stepping stones bridging the Atlantic or the Pacific populations have been found yet that would facilitate a worldwide distribution of a single species. In addition, sponge larvae are known to typically have short lifespans (see Maldonado, 2006). There are no data on the present or past existence of barrel sponges in the Eastern Pacific, which might potentially explain the haplotype overlaps as an historical consequence of gene flow between both regions (see in this context Knowlton et al., 1993; Knowlton \& Weigt, 1998).

Why does the cytochrome oxidase 1 display overlapping haplotypes? We conclude that Xestospongia mitochondrial systematics suffers from factors that mask the distinctiveness of the individual lineages. This can occur if divergence time for the cytochrome marker is longer than the divergence time of the two sibling species (Charlesworth, 2010). In other words, the polymorphisms occurred before descendants split into two separate species. These so-called ancient polymorphisms explain the overlapping haplotype distribution among the widely distributed barrel sponge populations rather than the presence of a single cosmopolitan barrel sponge species, although additional gene loci are required to test this hypothesis (see e.g. Wu, 1991; Takahata \& Satta, 1997; Rannala \& Yang, 2003; Zhou et al., 2007). The distribution of morphological, ecological and biochemical features of the three barrel sponge species strongly suggest the presence of ancient polymorphisms and explain the presence of identical haplotypes for morphotypes in both $X$. muta and $X$. testudinaria barrel sponges (Lopez-Legentil \& 
Table 3. Pairwise $F_{\mathrm{ST}}$ values between populations of $X$. testudinaria

\begin{tabular}{|c|c|c|c|c|c|c|c|c|c|c|}
\hline Population & $\begin{array}{l}\text { Saudi } \\
\text { Arabia }\end{array}$ & Tanzania & Taiwan & Thailand & $\begin{array}{l}\text { West } \\
\text { Java }\end{array}$ & $\begin{array}{l}\text { Central } \\
\text { Java }\end{array}$ & $\begin{array}{l}\text { East Java, } \\
\text { Bali, } \\
\text { Sumba }\end{array}$ & $\begin{array}{l}\text { North } \\
\text { Sulawesi }\end{array}$ & $\begin{array}{l}\text { South and } \\
\text { South-east } \\
\text { Sulawesi }\end{array}$ & $\begin{array}{l}\text { Great } \\
\text { Barrier Reef } \\
\text { \& Solomons }\end{array}$ \\
\hline Saudi Arabia & 0.00000 & & & & & & & & & \\
\hline Tanzania & 0.64309 & 0.00000 & & & & & & & & \\
\hline Taiwan & 0.79412 & -0.08484 & 0.00000 & & & & & & & \\
\hline Thailand & 0.65982 & $0.53306^{*}$ & $0.58250^{*}$ & 0.00000 & & & & & & \\
\hline West Java & 0.20755 & $0.36607^{*}$ & $0.41935^{*}$ & $0.43917^{*}$ & 0.00000 & & & & & \\
\hline Central Java & 0.68966 & -0.06814 & -0.11078 & $0.53185^{*}$ & 0.34472 & 0.00000 & & & & \\
\hline $\begin{array}{l}\text { East Java, Bali, } \\
\quad \text { Sumba }\end{array}$ & 0.18919 & 0.34050 & 0.37838 & $0.37377^{*}$ & 0.09950 & 0.33154 & 0.00000 & & & \\
\hline $\begin{array}{l}\text { North } \\
\quad \text { Sulawesi }\end{array}$ & 0.24492 & $0.39836^{*}$ & $0.44124^{*}$ & 0.14689 & $0.20787^{*}$ & $0.41011^{*}$ & 0.20305 & 0.00000 & & \\
\hline $\begin{array}{l}\text { South and } \\
\text { South-east } \\
\text { Sulawesi }\end{array}$ & 0.32216 & $0.43221^{*}$ & $0.47371^{*}$ & 0.05110 & 0.22752 & $0.43020^{*}$ & 0.11111 & -0.01047 & 0.00000 & \\
\hline $\begin{array}{l}\text { Great Barrier } \\
\text { Reef \& } \\
\text { Solomons }\end{array}$ & 1.00000 & 0.01573 & 0.00000 & $0.70612^{*}$ & $0.52703^{*}$ & 0.02778 & $0.54002^{*}$ & $0.50116^{*}$ & $0.60752^{*}$ & 0.00000 \\
\hline
\end{tabular}

*Significant values at $P<0.005$ after Bonferroni corrections.

Table 4. Hierarchical analysis of molecular variance (AMOVA) based on the $\mathrm{I}_{3}-\mathrm{M}_{11}$ region of $X$. testudinaria

\begin{tabular}{lccll}
\hline Source of variation & d.f. & $\begin{array}{l}\text { Sum of } \\
\text { squares }\end{array}$ & $\begin{array}{l}\text { Variance } \\
\text { components }\end{array}$ & $\begin{array}{l}\text { Percentage } \\
\text { of variation }\end{array}$ \\
\hline Among populations & 9 & 20.323 & $0.13530 \mathrm{Va}$ & 32.49 \\
Within populations & 201 & 56.506 & $0.28112 \mathrm{Vb}$ & 67.51 \\
Total & 210 & 76.828 & 0.41643 & \\
Fixation $\left(F_{\mathrm{ST}}\right)$ index & $0.32491^{*}$ & & & \\
\hline
\end{tabular}

*Significant values at $P<0.005$ after Bonferroni corrections.

Table 5. Spicule dimensions of the barrel sponge type specimens

\begin{tabular}{|c|c|c|}
\hline Species & Spicule length & Spicule width \\
\hline $\begin{array}{l}\text { X. testudinaria } \\
\text { (BMNH } \\
\text { 1881.10.21.266) }\end{array}$ & $174.95-277.17-331.71 \mu \mathrm{m}$ & $8.34-14.67-21.65 \mu \mathrm{m}$ \\
\hline $\begin{array}{l}X . \text { bergquistia } \\
\quad(\mathrm{QM} \text { G25018) }\end{array}$ & $303.28-352.29-378.09 \mu \mathrm{m}$ & $4.96-11.54-16.26 \mu \mathrm{m}$ \\
\hline $\begin{array}{r}\text { X. muta (MCZ } \\
\text { PORa-6449) }\end{array}$ & $192.31-367.67-446.44 \mu \mathrm{m}$ & $3.39-14.19-22.61 \mu \mathrm{m}$ \\
\hline
\end{tabular}

Minimum-mean-maximum.

Pawlik, 2009). These ancient polymorphisms, in combination with the slow mitochondrial substitution rates in poriferans, prevent the formation of monophyletic species based on cox 1 data and falsely suggest the presence of cosmopolitan lineages, which is a concept successively rejected in the literature on sponges and other marine taxa (see Palumbi et al., 1997; Solé-Cava \& Boury-Esnault, 1999; Wörheide et al., 2008). This is particularly evident since microsatellites, which are faster evolving independent markers, clearly show the distinction between $X$. bergquistia (including the type material) and $X$. testudinaria samples (Bell et al., $2014 \mathrm{a}, \mathrm{b})$. These results imply that the I3-M11 cannot be regarded as universally suitable for detecting species boundaries in all demosponges.

\section{The suitability of cytochrome oxidase 1 to resolve barrel sponge intra-specific relationships}

Nucleotide diversity $(\pi)$ is a measure of genetic variation, which is applied to calculate the degree of polymorphism in a population. Therefore, the higher the $\pi$ value, the more suitable is a marker in assessing intraspecific genetic diversity. The low variation in mitochondrial genomes observed in several non-bilaterian taxa (see e.g. Shearer et al., 2002; Huang et al., 2008) generally restricts the use of mitochondrial proteins as markers for population analyses in demosponges. However, a higher $\pi$ value on the $3^{\prime}$ (I3-M11) partition in mitochondrial DNA would suggest that this marker is more suitable to resolve genetic diversity compared with the $5^{\prime}$ partition. For X. muta, Lopez-Legentil \& Pawlik (2009) found a nucleotide diversity of $\pi=0.00058$ in the $5^{\prime}$ partition, contrasting the much higher nucleotide diversity of $\pi=0.0039$ in the $\mathrm{I}_{3}-\mathrm{M}_{11}$ partition, which restricts the use of the $5^{\prime}$ partition for intraspecific analyses and highlights the use of the I3-M11 partition for these purposes (see additional examples in Uriz \& Turon, 2012). Among the Indo-Pacific X. testudinaria six haplotypes were sampled over a range of more than $10,000 \mathrm{~km}$ extending from the Red Sea to Melanesia with $\pi=0.00290$ in the $\mathrm{I}_{3}-\mathrm{M}_{11}$ fragment. Five of these haplotypes were detected in specimens from the Indonesian archipelago in an area of $2300 \mathrm{~km}$ distance $(\pi=0.00302$ west Java to north Sulawesi). Nevertheless, our analysis clearly highlights that the application of $\mathrm{I}_{3}-\mathrm{M}_{11}$ in barrel sponges is only suitable when the correct boundaries of the target species are defined. Among Indo-Pacific sponges all haplotypes of X. bergquistia, of which the I3-M11 fragment has been sequenced for the first time, overlap with haplotypes of $X$. testudinaria. Likewise $50 \%$ of the haplotypes of the Caribbean X. muta found by Lopez-Legentil \& Pawlik (2009) are shared with Indo-Pacific haplotypes. Consequently, prior to the application of $\mathrm{I}_{3}-\mathrm{M}_{11}$ on the intraspecific relationships of barrel sponges, the correct assignment to either barrel sponge species is mandatory. 


\section{Implications for the genetic diversity and population structure of Xestospongia testudinaria}

In Xestospongia testudinaria we recognize a major difference in common haplotypes among regions. For instance, $\mathrm{C}_{2}$ is the most common haplotype in Tanzania, Taiwan and the Great Barrier Reef. On the other hand, $\mathrm{C}_{1}$ is the most common haplotype in Sulawesi and Thailand, and is also only present in those areas. One haplotype is found in Tanzania (Indian Ocean) only. The occurrence of major haplotypes has been suggested to be influenced by environmental factors such as currents or anthropogenic effects (Lopez-Legentil \& Pawlik, 2009; Swierts et al., 2013), and shows an eco-geographic heterogeneity in the Indo-Pacific. In addition, the hierarchical AMOVA and overall $F_{\mathrm{ST}}$ results display genetic structuring for $X$. testudinaria, which also corroborated the results of the geographically narrow scale studies of north Sulawesi (Swierts et al., 2013) and south-east Sulawesi (Bell et al., 2014a) populations.

The existence of different external morphotypes in X. testudinaria with distinct haplotypes, which likely represent reproductively isolated rather than ecophenotypic varieties, implies the presence of a $X$. testudinaria species complex composed of several sympatric species (Swierts et al., 2013) (see also Bell et al., 2014a). Likewise, in $X$. muta, two morphotypes (smooth and digitate) were found to have different genotypes although the authors assume that hybridization prevents their separation (Lopez-Legentil \& Pawlik, 2009). The presence of different $X$. muta lineages is also evident from different sterol compositions in three specimens of this species examined by Fromont et al. (1994), although they did not assign the different chemotypes to morphotypes. Nevertheless, our understanding of Xestospongia barrel sponge species with respect to their global genetic structuring and diversity is still limited due to unbalanced sample sizes and insufficient numbers of sequences at the regional scale (e.g. in the Solomon Islands, Great Barrier Reef, Thailand, Taiwan, Tanzania, Red Sea), including potentially missed haplotypes in some regions. These should be addressed in future analyses. Because of high sample numbers from one specific area and low numbers from other areas, we might have missed the occurrence of other haplotypes. For this reason, a more balanced sample size is required in order to get more accurate results for the future study of spatial relationships in every barrel sponge species, particularly $X$. testudinaria and $X$. bergquistia in the Indo-Pacific. Likewise, the utilization of nuclear intron markers, such as ATPS-beta (Bentlage \& Wörheide, 2007; Wörheide et al., 2008) could be beneficial to support our understanding of barrel sponge relationships.

\section{SUPPLEMENTARY MATERIAL}

To view supplementary material for this article, please visit http://dx.doi.org/10.1017/So025315415001149.

\section{ACKNDWLEDGEMENTS}

ES would like to thank DAAD (German Academic Exchange Service) for the award of a PhD Fellowship. In addition, ES acknowledges a Martin Fellowship from the Naturalis Biodiversity Center. The laboratory assistance from Gabriele Büttner, Simone Schätzle and Astrid Schuster, constructive criticism from Sergio Vargas, Gaurav Shimpi (Molecular Palaeobiology research group at LMU Munich) and Rob van Soest (The Naturalis Biodiversity Center, the Netherlands), as well as samples provided by Ratih Aryasari (Biology Faculty, Gadjah Mada University Indonesia), Elisabeth Crovetto, Yusheng Huang (National Penghu University of Science and Technology, Taiwan), Merrick Ekins (Queensland Museum, Australia), Adam Baldinger of Harvard University (Museum of Comparative Zoology) and Emma Sherlock (BMNH), are highly appreciated. We also thank Jane Fromont and another anonymous reviewer for constructive criticism that improved the manuscript considerably.

\section{REFERENCES}

Akaike H. (1974) A new look at the statistical model identification. IEEE Transactions on Automatic Control 19, 716-723.

Becking L.E., Cleary D.F.R. and de Voogd N.J. (2013) Sponge species composition, abundance, and cover in marine lakes and coastal mangroves in Berau, Indonesia. Marine Ecology Progress Series 481, $105-120$.

Bell J.J. (2007) The use of volunteers for conducting sponge biodiversity assessments and monitoring using a morphological approach on IndoPacific coral reefs. Aquatic Conservation: Marine and Freshwater Ecosystems 17, 133-145.

Bell J.J. (2008) The functional roles of marine sponges. Estuarine, Coastal and Shelf Science 79, 341-353.

Bell J.J., Smith D., Hannan D., Haris A., Jompa J. and Thomas L. (2014a) Resilience to disturbance despite limited dispersal and selfrecruitment in tropical barrel sponges: implications for conservation and management. PLoS ONE 9, e91635.

Bell J.J., Smith D., Hannan D., Haris A. and Thomas L. (2014b) Isolation and characterisation of twelve polymorphic microsatellite markers for Xestospongia spp. and their use for confirming species identity. Conservation Genetics Resources 6, 105-106.

Bellwood D.R. and Meyer C.P. (2009) Searching for heat in a marine biodiversity hotspot. Journal of Biogeography 36, 569-576.

Bentlage B. and Wörheide G. (2007) Low genetic structuring among Pericharax heteroraphis (Porifera: Calcarea) populations from the Great Barrier Reef (Australia), revealed by analysis of rDNA and nuclear intron sequences. Coral Reefs 26, 807-816.

Blanquer A. and Uriz M.-J. (2007) Cryptic speciation in marine sponges evidenced by mitochondrial and nuclear genes: a phylogenetic approach. Molecular Phylogenetics and Evolution 45, 392-397.

Boury-Esnault N. (2006) Systematics and evolution of Demospongiae. Canadian Journal of Zoology 84, 205-224.

Briggs J.C. (1999) Coincident biogeographic patterns: Indo-West Pacific ocean. Evolution 53, 326-335.

Calcul L., Longeon A., Mourabit A.A., Guyot M. and Bourguet-Kondracki M.L. (2003) Novel alkaloids of the aaptamine class from an Indonesian marine sponge of the genus Xestospongia. Tetrahedron 59, 6539-6544.

Cao S., Foster C., Brisson M., Lazo J.S. and Kingston D.G.I. (2005) Halenaquinone and xestoquinone derivatives, inhibitors of $\mathrm{Cdc} 25 \mathrm{~B}$ phosphatase from a Xestospongia sp. Bioorganic \& Medicinal Chemistry 13, 999-1003. 
Carballo J., Naranjo S. and García-Gómez J. (1996) Use of marine sponges as stress indicators in marine ecosystems at Algeciras bay (southern Iberian Peninsula). Marine Ecology Progress Series 135, $109-122$.

Cárdenas P., Pérez T. and Boury-Esnault N. (2012) Sponge systematics facing new challenges. Advances in Marine Biology 61, 79-209.

Charlesworth D. (2010) Don't forget the ancestral polymorphisms. Heredity (Edinburgh) 105, 509-510.

Cleary D.F.R. and de Voogd N.J. (2007) Environmental associations of sponges in the Spermonde Archipelago, Indonesia. Journal of the Marine Biological Association of the United Kingdom 87, 1669-1676.

Clement M., Posada D. and Crandall K.A. (2000) TCS: a computer program to estimate gene genealogies. Molecular Ecology 9, 16571659 .

Darriba D., Taboada G.L., Doallo R. and Posada D. (2012) jModelTest 2: more models, new heuristics and parallel computing. Nature Methods 9, 772 .

de Goeij J.M., van Oevelen D., Vermeij M.J.A., Osinga R., Middelburg J.J., de Goeij A.F.P.M. and Admiraal W. (2013) Surviving in a marine desert: the sponge loop retains resources within coral reefs. Science $342,108-110$.

de Queiroz K. (2007) Species concepts and species delimitation. Systematic Biology 56, 879-886.

de Voogd N.J. and Cleary D.F.R. (2007) Relating species traits to environmental variables in Indonesian coral reef sponge assemblages. Marine and Freshwater Research 58, 240-249.

de Voogd N.J. and Cleary D.F.R. (2008) An analysis of sponge diversity and distribution at three taxonomic levels in the Thousand islands/ Jakarta bay reef complex, West-Java, Indonesia. Marine Ecology 29 , 205-215.

Edgar R.C. (2004) MUSCLE: multiple sequence alignment with high accuracy and high throughput. Nucleic Acids Research 32, 1792- 1797

Erpenbeck D., Breeuwer J.A.J., Parra-Velandia F.J. and van Soest R.W.M. (2006a) Speculation with spiculation? - Three independent gene fragments and biochemical characters versus morphology in demosponge higher classification. Molecular Phylogenetics and Evolution 38, 293-305.

Erpenbeck D., Breeuwer J.A.J., van der Velde H.C. and Soest R.W.M. (2002) Unravelling host and symbiont phylogenies of halichondrid sponges (Demospongiae, Porifera) using a mitochondrial marker. Marine Biology 141, 377-386.

Erpenbeck D., Hooper J.N.A. and Woerheide G. (2006b) CO1 phylogenies in diploblasts and the 'Barcoding of Life' - are we sequencing a suboptimal partition? Molecular Ecology Notes 61, 550-553.

Erpenbeck D., Knowlton A.L., Talbot S.L., Highsmith R.C. and van Soest R.W.M. (2003) A molecular comparison of Alaskan and North East Atlantic Halichondria panicea (Pallas 1766) (Porifera: Demospongiae) populations. Bollettino Museo Istituti Universita Genova 68, 319-325.

Erpenbeck D. and van Soest R.W.M. (2007) Status and perspective of sponge chemosystematics. Marine Biotechnology 9, 2-19.

Excoffier L., Laval G. and Schneider S. (2005) Arlequin ver. 3.0: an integrated software package for population genetics data analysis. Evolution Bioinformatics Online 1, 47-50.

Fromont J. (1988) Aspects of the reproductive biology of Xestospongia testudinaria (Great Barrier Reef). In Choat J.H. (ed.) The 6th Coral Reef Symposium 8-12 August, Volume 2. Australia, pp. 685-691.

Fromont J. (1991) Descriptions of species of the Petrosida (Porifera: Demospongiae) occurring in the tropical waters of the Great Barrier
Reef. Beagle: Records of the Museums and Art Galleries of the Northern Territory 8, 73-95.

Fromont J. and Bergquist P.R. (1994) Reproductive biology of three sponge species of the genus Xestospongia (Porifera: Demospongiae: Petrosida) from the Great Barrier Reef. Coral Reefs 13, 119-126.

Fromont J., Kerr S., Kerr R., Riddle M. and Murphy P. (1994) Chemotaxonomic relationships within, and comparisons between, the orders Haplosclerida and Petrosida (Porifera: Demospongiae) using sterol complements. Biochemical Systematics and Ecology 22, 735-753.

Hoeksema B. (2007) Delineation of the Indo-Malayan centre of maximum marine biodiversity: the coral triangle. In Renema W. (ed.) Biogeography, time, and place: distributions, barriers, and islands. Volume 29. Dordrecht: Springer, pp. 117-178.

Hooper J.N.A. and van Soest R.W.M. (2002) Systema Porifera: a guide to the classification of sponges. New York, NY: Kluwer Academic/Plenum Publishers.

Hooper J.N.A. and Wiedenmayer F. (1994) Porifera. In Wells A. (ed.) Zoological catalogue of Australia. Melbourne: CSIRO, pp. 1-621.

Huang D., Meier R., Todd P. and Chou L. (2008) Slow mitochondrial COI sequence evolution at the base of the metazoan tree and its implications for DNA barcoding. Journal of Molecular Evolution 66, 167174 .

Jones G.P., Srinivasan M. and Almany G.R. (2007) Population connectivity and conservation of marine biodiversity. Oceanography 20, 100111.

Kayal E. and Lavrov D.V. (2008) The mitochondrial genome of Hydra oligactis (Cnidaria, Hydrozoa) sheds new light on animal mtDNA evolution and cnidarian phylogeny. Gene 410, 177-186.

Kelly-Borges M., Bergquist P.R. and Bergquist P.L. (1991) Phylogenetic relationships within the order Hadromerida (Porifera, Demospongiae, Tetractinomorpha) as indicated by ribosomal RNA sequence comparisons. Biochemical Systematics and Ecology 19, 117-125.

Knowlton N. and Weigt L. (1998) New dates and new rates for divergence across the Isthmus of Panama. Proceedings of the Royal Society of London, Biological Sciences 265, 2257-2263.

Knowlton N., Weigt L., Solorzano L., Mills D. and Bermingham E. (1993) Divergence in proteins, mitochondrial DNA, and reproductive compatibility across the Isthmus of Panama. Science 260, 1629-1632.

Librado P. and Rozas J. (2009) DnaSP v5: a software for comprehensive analysis of DNA polymorphism data. Bioinformatics 25, 1451-1452.

Lopez-Legentil S. and Pawlik J.R. (2009) Genetic structure of the Caribbean giant barrel sponge Xestospongia muta using the $\mathrm{I}_{3}-\mathrm{M}_{11}$ partition of COI. Coral Reefs 28, 157-165.

Maldonado M. (2006) The ecology of the sponge larva. Canadian Journal of Zoology 84, 175-194.

Montalvo N.F. and Hill R.T. (2011) Sponge-sssociated bacterial symbionts are strictly maintained to two closely-related but geographically distant sponge hosts. Applied and Environmental Microbiology 77, 7207-7216.

Newman D.J. and Cragg G.M. (2012) Natural products as sources of new drugs over the 30 years from 1981 to 2010. Journal of Natural Products $75,311-335$

Palumbi S.R., Grabowsky G., Duda T.F. Jr, Geyer L. and Tachino N. (1997) Speciation and population genetic structure in tropical Pacific sea urchins. Evolution 51, 1506-1517.

Powell A. (2013) The Impacts of Predation and Habitat Degradation on Coral Reef Sponge Assemblages in SE Sulawesi, Indonesia. PhD thesis. School of Biological Sciences, Victoria University of Wellington, Wellington, New Zealand. 
Rannala B. and Yang Z. (2003) Bayes estimation of species divergence times and ancestral population sizes using DNA sequences from multiple loci. Genetics 164, 1645-1656.

Reveillaud J., van Soest R.W.M., Derycke S., Picton B., Rigaux A. and Vanreusel A. (2011) Phylogenetic relationships among NE Atlantic Plocamionida Topsent (1927) (Porifera, Poecilosclerida): underestimated diversity in reef ecosystems. PLoS ONE 6, e16533.

Rice W.R. (1989) Analyzing tables of statistical tests. Evolution 43, 223225.

Ritson-Williams R., Becerro M.A. and Paul V.J. (2005) Spawning of the giant barrel sponge Xestospongia muta in Belize. Coral Reefs 24, 160.

Ronquist F., Teslenko M., van der Mark P., Ayres D.L., Darling A., Höhna S., Larget B., Liu L., Suchard M.A. and Huelsenbeck J.P. (2012) MrBayes 3.2: efficient Bayesian phylogenetic inference and model choice across a large model space. Systematic Biology 61, $539-542$.

Rot C., Goldfarb I., Ilan M. and Huchon D. (2006) Putative crosskingdom horizontal gene transfer in sponge (Porifera) mitochondria BMC Evolutionary Biology 6, 71 .

Ruiz G.M., Torchin M.E. and Grant K. (2007) Using the Panama canal to test predictions about tropical marine invasions. In Lang M.A., MacIntyre I.G. and Rützler K. (ed.) Smithsonian Contributions to the Marine Sciences. Volume 38. Washington, DC: Smithsonian Institution Scholarly Press, pp. 529.

Shearer T.L., van Oppen M.J.H., Romano S.L. and Wörheide G. (2002) Slow mitochondrial DNA sequence evolution in the Anthozoa (Cnidaria). Molecular Ecology 11, 2475-2487.

Silvestro D. and Michalak I. (2012) RaxmlGUI: a graphical front-end for RAxML. Organisms Diversity and Evolution 12, 335-337.

Solé-Cava A.M. and Boury-Esnault N. (1999) Patterns of intra and interspecific genetic divergence in marine sponges. Memoirs of the Queensland Museum 44, 591-602.

Solé-Cava A.M. and Wörheide G. (2007) The perils and merits (or the Good, the Bad and the Ugly) of DNA barcoding of sponges - a controversial discussion. In Custódio M.R., Lôbo-Hajdu G., Hajdu E. and Muricy G. (ed.) Porifera research: biodiversity, innovation and sustainability. Série Livros 28. Rio de Janeiro: Museu Nacional, pp. 603-612.

Stamatakis A., Hoover P. and Rougemont J. (2008) A rapid bootstrap algorithm for the RAxML web servers. Systematic Biology 57, 758-771.

Sutherland K., Porter J. and Torres C. (2004) Disease and immunity in Caribbean and Indo-Pacific zooxanthellate corals. Marine Ecology Progress Series 266, 273-302.

Swierts T., Peijnenburg K.T.C.A., de Leeuw C., Cleary D.F.R., Hörnlein C., Setiawan E., Wörheide G., Erpenbeck D. and de Voogd N.J. (2013) Lock, stock and two different barrels: comparing the genetic composition of morphotypes of the Indo-Pacific sponge Xestospongia testudinaria. PLoS ONE 8, e74396.

Tajima F. (1989) Statistical method for testing the neutral mutation hypothesis by DNA polymorphism. Genetics 123, 585-595.

Takahata N. and Satta Y. (1997) Evolution of the primate lineage leading to modern humans: phylogenetic and demographic inferences from
DNA sequences. Proceedings of the National Academy of Sciences USA 94, 4811-4815.

Uriz M.J. and Turon X. (2012) Sponge ecology in the molecular era. Advances in Marine Biology 61, 345-410.

van Soest R.W.M. (1989) The Indonesian sponge fauna: a status report. Netherlands Journal of Sea Research 23, 223-230.

van Soest R.W.M., Boury-Esnault N., Vacelet J., Dohrmann M., Erpenbeck D., de Voogd N.J., Santodomingo N., Vanhoorne B., Kelly M. and Hooper J.N.A. (2012) Global diversity of sponges (Porifera). PLoS ONE 7, e35105.

Vargas S., Schuster A., Sacher K., Büttner G., Schätzle S., Läuchli B., Hall K., Hooper J.N.A., Erpenbeck D. and Wörheide G. (2012) Barcoding sponges: an overview based on comprehensive sampling. PLOS ONE 7, e39345.

Veron J.E.N. (1995) Corals in space and time: biogeography \& evolution of the Scleractinia. Sydney: University of New South Wales Press, pp. $1-321$

Wapstra M. and van Soest R.W.M. (1987) Sexual reproduction, larval morphology and behaviour in Demosponges from the Southwest of the Netherlands. In Vacelet J. and Boury-Esnault N. (eds) Taxonomy of Porifera. Berlin: Springer-Verlag, pp. 281-307.

Wörheide G., Epp L. and Macis L. (2008) Deep genetic divergences among Indo-Pacific populations of the coral reef sponge Leucetta chagosensis (Leucettidae): founder effects, vicariance, or both? BMC Evolutionary Biology 8, 24.

Wörheide G., Sole-Cava A.M. and Hooper J.N.A. (2005) Biodiversity, molecular ecology and phylogeography of marine sponges: patterns, implications and outlooks. Integrative and Comparative Biology 45, $377-385$.

Wu C.-I. (1991) Inferences of species phylogeny in relation to segregation of ancient polymorphisms. Genetics 127, 429-435.

Xavier J.R., Rachello-Dolmen P.G., Parra-Velandia F.J., Schönberg C.H.L., Breeuwer J.A. and van Soest R.W.M. (2010) Molecular evidence of cryptic speciation in the "cosmopolitan" excavating sponge Cliona celata (Porifera, Clionaidae). Molecular Phylogenetics and Evolution 56, 13-20.

and

Zhou R., Zeng K., Wu W., Chen X., Yang Z., Shi S. and Wu C.-I. (2007) Population genetics of speciation in nonmodel organisms: I. Ancestral polymorphism in mangroves. Molecular Biology and Evolution 24, $2746-2754$.

\section{Correspondence should be addressed to:}

N.J. de Voogd and D. Erpenbeck

Naturalis Biodiversity Center, Leiden, the Netherlands; Department of Earth and Environmental Sciences, Palaeontology \& Geobiology, and GeoBio-Center, LudwigMaximilians-Universität München, Munich, Germany email: nicole.devoogd@naturalis.nl, erpenbeck@lmu.de 